JEL Classification: C23, D24, F2

Keywords: productivity, foreign ownership, FDI

\title{
Foreign Ownership and Corporate Performance: The Czech Republic at EU Entry"
}

Štěpán JURAJDA-CERGE-EI, Prague, and Research Affiliate at CEPR, London and Research Fellow at IZA, Bonn (stepan.jurajda@cerge-ei.cz), corresponding author

Juraj STANČíK_-CERGE-EI, Prague, and Scientific Fellow at IPTS (DG JRC, European Commission) in Seville (juraj.stancik@cerge-ei.cz)

Abstract

Does foreign ownership improve corporate performance, or do foreign firms merely select more productive targets for takeover? Do workers benefit from foreign acquisitions? We answer these questions by comparing the beforelafter change in several performance indicators of Czech firms subject to foreign takeover after 1997, i.e., after the initial waves of privatization were completed, with the corresponding performance change of matched companies that remained domestically owned until 2005. We find that the impact of foreign investors on domestic acquisitions is significantly positive only in non-exporting manufacturing industries or those with low import penetration, while it is small in both services and manufacturing industries competing on international markets.

\section{Introduction}

Foreign direct investment (FDI) is likely to be one of the key channels of economic development for middle-income countries, particularly so for the postcommunist economies of Central Europe (e.g., Alfaro et al., 2004; Neuhaus, 2006). Foreign-owned companies, a group that includes both greenfields and foreign acquisitions, are consistently more productive than domestically owned firms, as Sabirianova et al. (2005) demonstrate for the Czech Republic and Russia. ${ }^{1}$ Taking the productivity advantage of FDI as a given, a large literature therefore studies its indirect impacts on domestic companies - productivity spillovers within and across industries (e.g., Javorcik, 2004; Gorodnichenko et al., 2007). However, there is somewhat less work available measuring the direct causal productivity effects of foreign takeovers of domestic companies, even though such measurements are important for evaluating the benefits of greenfield vs. brownfield FDI support and for understanding the nature of FDI flows.

There is, of course, a large literature studying the effects of early-transition privatization of state-owned companies in post-communist economies. In one of the most complete analyses, Brown et al. (2006) suggest that privatizing state-owned companies to foreign entities during the 1990s generated larger productivity gains than privatization to domestic owners. In several transition economies, however, large FDI inflows started only after the mass privatization programs were completed.

\footnotetext{
*We would like to thank Jan Hanousek, Peter Katuščák, and Evžen Kočenda for useful comments. Support from GACR grant No. 402/06/1293 is gratefully acknowledged, as is access to the ASPEKT data provided by Jan Hanousek.

${ }^{1}$ For evidence on the productivity dominance of foreign-owned firms, see Barba Navaretti and Venables (2004) and Bellak (2004). Helpman et al. (2004) and Girma et al. (2004) study the superior productivity of domestic multinationals with respect to domestic exporters and non-exporters.
} 
The Czech Republic is a case in point, as it received a massive inflow of foreign capital only after $1997 .^{2}$

In this paper, we therefore provide evidence on the recent direct effects of FDI. We assess the effects of over 300 cases of foreign takeovers observed in a sample of Czech firms between 1997 and 2005. We do not differentiate takeover effects by the ownership type of domestic companies, so our analysis is not related to the issue of privatization. Unlike most of the work on privatization or, indeed, on foreign takeovers, we analyze not only manufacturing companies, but also the service sector, where the share of foreign capital as of 2005 was about $40 \%$ of that in manufacturing industries. ${ }^{3}$ We contrast the takeover effects not only across the services/ manufacturing divide, but also across the groups of exporting and non-exporting manufacturing industries, as these are likely to differ in terms of the strategies that multinationals use when entering a given sector. While acquiring a domestic company in a non-exporting sector eliminates a potential domestic competitor, acquiring a local company in an internationally competitive industry is more likely to be motivated by high domestic-company performance and may therefore lead to smaller takeover productivity improvements. Put differently, acquiring a domestic firm exposed to international competition may generate smaller takeover effects, as such firm is already "disciplined" by international competition. ${ }^{4}$ Similarly, we contrast the results across manufacturing industries that face significant import penetration (international competition) and those that do not.

Further, we follow Brown et al. (2010) in studying not only the productivity effects of ownership changes, but also the effects on workers. Specifically, we ask whether foreign takeovers affect the wage bill of the company, i.e., the total earnings of employees. The related question of interest to workers as well as policy makers is whether scale effects of takeovers outweigh the cost-cutting potentially associated with the higher productivity that foreign owners impose on their acquisitions and, therefore, whether foreign acquisitions ultimately benefit domestic workers, be it through higher wages per worker or higher employment. Unfortunately, employment is not available in our data so we cannot decompose the wage bill effect into employment and wage rate effects.

A fundamental problem with the identification of these causal effects is that multinational companies are likely to select the best domestic firms as acquisition targets. In the absence of credible instrumental variables, most studies attempt to achieve progress on causality by conditioning on pre-takeover performance. An increasingly popular technique-see, for example, Arnold and Javorcik (2009) or Girma et al. (2007) — is to match foreign acquisitions to domestic firms with a similar

\footnotetext{
${ }^{2}$ Benefiting from investment subsidies and tax breaks introduced in 1997, Czech FDI inflows rose from below 3\% of GDP in 1996 to 1997 to over 10\% during 1999 to 2002. As a result, Czech FDI stock per capita reached EUR 5,256 in 2005, the end of our sample frame, which compares favorably with the 2005 FDI stock in Slovakia $(2,721)$ or Poland $(2,070)$.

${ }^{3}$ Out of over ten studies of foreign ownership effects in the Czech Republic during the 1990s, the only one to cover the service sector is Kosová (2010), who focuses on the indirect effects of FDI. Outside Central Europe, only Aitken and Harrison (1999) work with non-manufacturing data. The related literature is discussed in more detail in Section 2.

${ }^{4}$ There is a growing theoretical literature on how firms choose modes of foreign market access, but little empirical work on the topic; see, for example, Nocke and Yeaple (2007) for a general equilibrium model with heterogeneous firms or Qiu and Wang (2011) for an empirical analysis of a multinational's choice between greenfield investment and cross-border merger.
} 
probability of being acquired by multinationals and to compare the before/after performance changes between the two groups. As argued by Blundell and Costa Dias (2000), this approach combines careful conditioning on observables through matching on pre-takeover performance (trends) with before/after differencing that eliminates time-constant unobservables. We follow their suggestion and apply the matched difference-in-differences approach to our sample of Czech manufacturing and service firms, effectively comparing the change in performance of companies taken over by foreign investors between the moment of acquisition and one to three years later with the corresponding change in performance of matched domestic companies.

Using several performance indicators, we find the impact of foreign investors on domestic acquisitions to vary across types of target industries. Based on data covering the experience of Czech firms around the moment of the Czech Republic's entry into the EU, we uncover significant effects of foreign takeovers only in the nonexporting manufacturing sector and, alternatively, in the sector with low import penetration, consistent with the argument that firms in highly open manufacturing industries successfully face direct international competition and do not need to be "disciplined" by foreign owners. Further, we find no effect of foreign takeovers on the performance of service-sector companies.

The paper is structured as follows. The next section covers the existing work on takeover effects and ownership change, with a focus on results available for the Czech Republic. Our empirical strategy and data are described in Sections 3 and 4, respectively, while Section 5 presents the findings. The last section concludes.

\section{Literature Review}

There are numerous studies estimating the direct effects that foreign investors have on the performance of domestic companies during the early-transition massprivatization period (for surveys, see, for example, Djankov and Murrell, 2002, or Estrin et al., 2009). In this section, we first highlight those that focus on the Czech Republic and we then discuss groups of studies of ownership effects that differ in their preferred estimation technique.

A small literature estimates the positive effects of foreign ownership on total factor productivity (TFP), or its growth, in the Czech Republic using data from 1992 to 1998 covering the mass privatization process (e.g., Djankov and Hoekman, 2000; Jarolím, 2000; Damijan et al., 2003; Evenett and Voicu, 2003). These studies typically use small samples of manufacturing or publicly traded firms to estimate linear regressions with exogeneity in foreign status (or sample selection corrections) based on various arguments, including the exclusion of the firm's initial efficiency or the relative size of the given firm within its industry from the company performance regression. In the most detailed and careful study of the Czech mass-privatization experience to date, Hanousek et al. (2007) instrument for ownership changes using pre-market initial conditions and detect positive effects of foreign ownership on various performance measures driven mainly by foreign industrial firms. ${ }^{5}$

\footnotetext{
${ }^{5}$ Several recent papers also ask about the indirect effects of FDI on domestic Czech companies through productivity spillovers within and across industries (see, for example, Kosová, 2010, or Stančík, 2007). The key identification problem of this literature, similar to the need for exogenous determinants of foreign ownership in the work on the direct effects of FDI, is to identify variation in industry FDI inflow that is not driven by (estimates of) future growth of that industry.
} 
The research on Czech firms undergoing mass privatization is typical of most of the existing work on ownership effects from other countries in that it relies on panel-data techniques and postulates exclusion restrictions that allow for instrumental variable (IV) strategies. Some of this work combines the IV approach with fixed-effects estimation conditioning on a lagged dependent variable and requires (weak) exogeneity of lagged outcome and control variables (e.g., Benfratello and Sembenelli, 2006). The identification of such dynamic GMM models, however, is fragile when the variables of interest are sufficiently persistent.

Convincing quasi-experiments affecting ownership but not performance are seldom found, especially once the focus shifts beyond pre-market initial conditions to late-transition data. Another strand of research thus attempts to control for the correlation between ownership type and company unobservables in a simple static regression framework using company fixed effects and/or time trends. A prime example of this body of work is provided by the analysis of long panel data from four transition countries by Brown et al. (2006), who suggest that privatizing state-owned companies to foreign entities generates larger productivity gains than privatization to domestic owners. The basic goal of these regressions is to compare the performance of domestic and foreign-owned firms after conditioning on both time-constant unobservables (captured by the firm fixed effects) and pre-takeover performance change (captured by the firm-specific time trends). However, to the extent that much of the data used in the estimation of these firm time trends comes from after the ownership change, these methods may "over-control" and lead to under-estimation of the effect of interest. ${ }^{6}$ Furthermore, regression-based techniques may suffer from a lack of "common support" (Barsky et al., 2002) when the characteristics of firms acquired by foreign investors differ from those of a significant share of firms in the data that remain domestic.

An increasingly popular alternative conditioning technique is to match foreign acquisitions to domestic firms with a similar probability of being acquired by multinationals based on pre-takeover performance and to compare the before/after performance changes between the two groups. Examples of this approach, which combines careful conditioning on observables through propensity score matching on pre-takeover performance (possibly including performance trends) with before/after differencing that eliminates time-constant unobservables, are the studies of Arnold and Javorcik (2009) and Girma et al. (2007), who study Indonesian and UK manufacturing firms, respectively, and uncover significant foreign-takeover TFP effects.

Finally, while there are several results available on the effects of foreign takeovers on firm productivity, less attention has been paid to the effects on firm wage bill and employment, even though these two variables are important from the perspective of the political economy of FDI (Conyon et al., 2002, is an early exception). Recently, Brown et al. (2010) combine evidence on productivity effects with estimates of wage and employment effects of ownership changes of manufacturing firms of four transition economies (but not the Czech Republic); they suggest that foreign takeovers have scale-expansion effects that dominate the productivityimprovement effects, leading to a positive effect on workers' wages.

\footnotetext{
${ }^{6}$ This issue can be addressed using pre- and post-acquisition trends.
} 
Similarly, there is so far little evidence on how foreign-takeover effects differ across different types of industries or investment strategies. The theory typically classifies FDI into market-oriented and export-oriented, with market-oriented FDI being attracted by the size and growth of the host market while export-oriented FDI looks for cost competitiveness and productivity. ${ }^{7}$ It is also argued that in contrast to horizontal FDI, vertical or export-oriented FDI often involves relocating parts of the production chain to the host country (Campos and Kinoshita, 2003). One may therefore expect the effects on local companies to differ across sectors more or less open to international competition. Companies operating in product markets exposed to international competition are more likely to operate according to international best practice and are therefore in less need of being "disciplined" by international owners. In contrast, if local markets are protected against foreign goods, foreign companies are likely to invest in those countries in order to access those markets.

In this paper, we apply matched difference-in-differences comparison to a sample of Czech manufacturing and service-sector firms from 1995-2005. Unlike the existing analyses of the Czech Republic, or indeed of other countries from Central Europe, we estimate the effects of foreign takeovers that took place after 1997, i.e., after the mass privatization programs were completed. Unlike almost all of the work on both transition and developing economies, we study the experience of not only manufacturing, but also service-sector firms, and we differentiate between industries with different levels of exposure to international competition. Finally, we also measure the consequences of foreign acquisitions not only for company performance indicators, but also for their wage bills - a variable more interesting for workers subject to such an ownership change.

\section{Estimation Approach}

To circumvent the selection into foreign-owned status ("cherry picking" by foreign investors), we draw on the microeconometric evaluation literature and employ propensity-score matching to compare changes in performance associated with foreign takeovers to changes in performance in highly similar companies that remain domestic. Specifically, one can estimate the causal effect of foreign ownership on a given outcome indicator by assuming that the assignment to foreign-owned status is as good as random conditional on observables summarized in the propensity score, i.e., within a group of firms that share a similar predicted probability of being acquired by foreign investors $P\left(X_{t-1}\right) \equiv P\left(F D I_{t}=1 \mid X_{t-1}\right)$, where $t$ corresponds to the timing of the foreign acquisition. The outcome measure of interest in our case consists of the difference between a company's performance at the time of being acquired and one to three years later, i.e., $Y_{t+k}-Y_{t}$, where $k=1,2,3$.

The causal effect of interest - the average effect of treatment on the treatedis defined as the difference between the average outcome measure of firms that were acquired by foreign investors, denoted $E\left[Y_{1, t+k}-Y_{1, t} \mid F D I_{t}=1\right]$, which is easy to obtain from data, and the hypothetical counterfactual outcome of these same firms had they not been acquired: $E\left[Y_{0, t+k}-Y_{0, t} \mid F D I_{t}=1\right]$. The counterfactual is esti-

\footnotetext{
${ }^{7}$ Alternatively, export-oriented FDI can be viewed as cost-seeking FDI; see, for example, ISGEP (2008).
} 
mated based on the conditional independence assumption (Rosenbaum and Rubin, 1983) as the average outcome of firms that were not acquired by foreign investors, but that had the same probability of being acquired as of time $t$ - the same value of the propensity score:

$$
E\left[Y_{0, t+k}-Y_{0, t} \mid F D I_{t}=1, P\left(X_{t-1}\right)\right]=E\left[Y_{0, t+k}-Y_{0, t} \mid F D I_{t}=0, P\left(X_{t-1}\right)\right]
$$

The probability of being acquired (the propensity score) is assumed to depend on a set of time-changing observable characteristics, chiefly firm-level balance-sheet indicators, entered both contemporaneously and lagged to capture pre-takeover performance trends; the exercise is performed within groups defined by (matching is "exact" on) year and industry. ${ }^{8}$ Equation (1) implies that a basic requirement for the implementation of the matching approach is a sufficiently large overlap between the distribution of the propensity score of the acquired and the domestic companies (the common support condition). ${ }^{9}$

\section{Data and Descriptive Evidence}

The company-level balance-sheet annual data used in this study come from the ASPEKT commercial database, which is a Czech source for the Amadeus EU-wide data and is widely used in empirical research (e.g., Hanousek et al., 2007; Hanousek et al., 2009). Crucially, the ASPEKT data provide information on companies' ownership structure and thus allow one to identify foreign-owned companies. We interpret a company as foreign-owned if it has at least $10 \%$ of its equity owned by a foreign investor. ${ }^{10}$

The purpose of the study is to contrast the performance of domestic firms that were acquired by foreign investors with that of firms that remain domestic-owned. We therefore disregard information on foreign-owned greenfields in most of the analysis. ${ }^{11}$ After dropping observations with inconsistent financial information, firms with fixed assets of less than CZK 1 million (approximately EUR 30,000), as well as industrial branches involving a strong regulatory role of the government, ${ }^{12}$ the resulting sample contains information on 4,049 companies from forty 2-digit NACE industrial sectors and covers the 1995-2005 period, generating 26,163 firmyear observations. ${ }^{13}$

\footnotetext{
${ }^{8}$ The procedure therefore compares FDI recipient firms with non-recipient firms at the same moment in time; the kernel matching procedure is implemented in the latest version of the ps-match2 Stata routine provided by Leuven and Sianesi (2003). Blundell and Costa Dias (2009) offer an intuitive summary of the estimation approach used here.

${ }^{9} \mathrm{An}$ assessment of the matching quality consists of checking whether the matching procedure is able to balance the distribution of the relevant variables across the control and treatment group. To this effect, we perform two-sample $t$-tests as suggested by Rosenbaum and Rubin (1985).

${ }^{10}$ This threshold is also used in the official definition of FDI by the Czech National Bank and in studies of firm-level data by Evenett and Voicu (2003), Damijan et al. (2003), and Javorcik (2004). The average share of a foreign investor in a Czech company in our data is $3 \%$. The average foreign share in companies with at least $10 \%$ foreign ownership is $51 \%$. We do not differentiate between various types of domestic ownership.

${ }^{11}$ Greenfields were preliminarily identified as firms newly appearing in the sample with (near) $100 \%$ foreign ownership; all such cases were then checked manually (information on these firms was found on the internet) to confirm that the observed firm is in fact not an acquisition of a previously domestically owned company.
} 
Table 1 Definition of Industry-Level FDI Variables

\begin{tabular}{ll}
\hline FDI share & $\begin{array}{l}\text { Foreign direct investment divided by fixed assets at the 2-digit } \\
\text { NACE industry level. (Source: Czech National Bank) }\end{array}$ \\
FDI share by takeovers & $\begin{array}{l}\text { Industry-level fixed assets of domestic companies acquired by } \\
\text { foreign investors divided by industry fixed assets. (Source: Aspekt) }\end{array}$ \\
FDI share by greenfields & $\begin{array}{l}\text { Industry-level fixed assets of companies built by foreign } \\
\text { investors divided by industry fixed assets. (Source: Aspekt) }\end{array}$ \\
\hline
\end{tabular}

\section{Table 2 Number of Companies by Year}

The column "always domestic" gives the number of companies observed in a given year that remain domestic throughout the sample frame; the column "before acquisition" gives the number of domestic companies observed in a given year that are to be acquired by a foreign entity later; the column "after acquisition" gives the number of observed companies that are foreign-owned as of a given year; the column " $N$ " gives the total number of firm observations in the sample, which contains no greenfields. The last column "acquisitions" gives the number of foreign acquisitions in a given year.

\begin{tabular}{lc|cc|cc}
\hline year & $\begin{array}{c}\text { always } \\
\text { domestic }\end{array}$ & $\begin{array}{c}\text { firm-year observations } \\
\text { before } \\
\text { acquisition }\end{array}$ & $\begin{array}{c}\text { after } \\
\text { acquisition }\end{array}$ & N & acquisitions \\
\hline 1995 & 1,841 & 244 & 0 & 2,085 & 0 \\
1996 & 2,093 & 262 & 5 & 2,360 & 5 \\
1997 & 2,236 & 210 & 64 & 2,510 & 59 \\
1998 & 2,275 & 192 & 94 & 2,561 & 30 \\
1999 & 2,302 & 162 & 126 & 2,590 & 36 \\
2000 & 2,271 & 126 & 163 & 2,560 & 47 \\
2001 & 2,242 & 81 & 199 & 2,522 & 51 \\
2002 & 2,230 & 56 & 211 & 2,497 & 31 \\
2003 & 2,159 & 31 & 221 & 2,411 & 29 \\
2004 & 1,984 & 10 & 220 & 2,214 & 23 \\
2005 & 1,638 & 0 & 215 & 1,853 & 13 \\
\hline Total & 23,271 & 1,374 & 1,518 & 26,163 & 324 \\
\hline
\end{tabular}

An overview of the year-ownership and industry-ownership structure of the sample is provided in Tables 2 and 3, respectively. In a typical year, there are over 2,000 companies in the data. We observe 324 cases of foreign takeovers, and foreign-owned data represent almost $6 \%$ of all firm-year observations. The timing of foreign acquisitions mimics the time series of aggregate FDI inflow as recorded by the Czech National Bank (CNB), rising swiftly after 1997. ${ }^{14}$ Table 3 shows that in some industries, as many as $20 \%$ of firms in our sample were acquired by foreign investors during the sample frame, while there are no foreign takeovers in several 2-digit industries. The share of foreign capital in each industry, which reflects both foreign takeovers and greenfields, also varies widely, from low levels in, for example,

\footnotetext{
${ }^{12}$ Agriculture, forestry, fishing, utilities, public administration, health and education; NACE codes 1, 2, 5, $41,75,80$, and 85 .

${ }^{13}$ We also observe 1,018 unique greenfields with foreign ownership in our sample, with 5,743 firm-year observations in total. Including the greenfields, our panel data thus have 31,906 observations.

14 To check for potential attrition bias related to ownership, we compared the exit rates of "alwaysdomestic" and "after-takeover" firms and found it nearly identical in all years.
} 
Table 3 FDI Share and Structure by Industry as of 2005

The column " $N$ " gives the number of companies in the sample observed at least once, while the second column shows the (cumulative) share of these companies taken over by foreign entities. The third column presents the official FDI share in industry fixed assets as of 2005 and the last one shows the share of FDI capital in companies acquired by foreign investors (as opposed to built by them). See Table 1 for variable definitions. A sector is considered to be export-oriented if it exports at least $50 \%$ of its production abroad on average over the 1995-2005 period.

\begin{tabular}{|c|c|c|c|c|c|}
\hline \multicolumn{2}{|c|}{ NACE } & $N$ & $\begin{array}{c}\text { Share } \\
\text { of takeovers }\end{array}$ & FDI share & $\begin{array}{c}\text { FDI share } \\
\text { by takeovers }\end{array}$ \\
\hline \multicolumn{6}{|c|}{ Low-export manufacturing } \\
\hline 15 & Food products and beverages & 327 & 0.09 & 0.23 & 0.03 \\
\hline 20 & Wood and wood products & 154 & 0.08 & 0.19 & 0.02 \\
\hline 21 & Pulp, paper and paper products & 29 & 0.14 & 0.51 & 0.02 \\
\hline 22 & Publishing and printing & 162 & 0.12 & 0.23 & 0.01 \\
\hline 23 & Coke, refined petroleum and nuclear fuel & 14 & 0.21 & 0.28 & 0.07 \\
\hline 26 & Other non-metallic mineral products & 161 & 0.08 & 0.38 & 0.01 \\
\hline 27 & Basic metals & 99 & 0.12 & 0.29 & 0.01 \\
\hline 28 & Fabricated metal products & 461 & 0.10 & 0.22 & 0.01 \\
\hline Tota & & 1,407 & 0.10 & 0.28 & 0.03 \\
\hline \multicolumn{6}{|c|}{ High-export manufacturing } \\
\hline 17 & Textiles & 95 & 0.09 & 0.17 & 0.02 \\
\hline 18 & Wearing apparel; dressing and dyeing of fur & 22 & 0.00 & 0.08 & 0.00 \\
\hline 19 & Leather and leather products & 25 & 0.08 & 0.03 & 0.00 \\
\hline 24 & Chemicals and chemical products & 139 & 0.12 & 0.31 & 0.03 \\
\hline 25 & Rubber and plastic products & 68 & 0.15 & 0.41 & 0.01 \\
\hline 29 & Machinery and equipment n.e.c. & 119 & 0.13 & 0.28 & 0.06 \\
\hline 30 & Office machinery and computers & 22 & 0.09 & 0.50 & 0.02 \\
\hline 31 & Electrical machinery and apparatus n.e.c. & 86 & 0.05 & 0.44 & 0.04 \\
\hline 32 & Radio, TV and communication equipment & 38 & 0.08 & 0.65 & 0.01 \\
\hline 33 & Medical, precision and optical instruments & 49 & 0.06 & 0.42 & 0.01 \\
\hline 34 & Motor vehicles, trailers and semi-trailers & 15 & 0.20 & 0.57 & 0.44 \\
\hline 35 & Other transport equipment & 13 & 0.08 & 0.13 & 0.04 \\
\hline 36 & Furniture; manufacturing n.e.c. & 27 & 0.07 & 0.12 & 0.01 \\
\hline 37 & Recycling & 36 & 0.03 & 0.17 & 0.03 \\
\hline Tota & & 754 & 0.10 & 0.38 & 0.04 \\
\hline \multicolumn{6}{|c|}{ Services } \\
\hline 50 & Sale and repair of motor vehicles & 140 & 0.06 & 0.14 & 0.01 \\
\hline 51 & Wholesale trade, except of motor vehicles & 663 & 0.06 & 0.32 & 0.01 \\
\hline 52 & Retail trade; repair of personal goods & 290 & 0.05 & 0.27 & 0.03 \\
\hline 55 & Hotels and restaurants & 49 & 0.04 & 0.06 & 0.01 \\
\hline 60 & Land transport; transport via pipelines & 22 & 0.09 & 0.08 & 0.00 \\
\hline 63 & Supporting and auxiliary transport activities & 10 & 0.00 & 0.01 & 0.00 \\
\hline 64 & Post and telecommunications & 9 & 0.11 & 0.52 & 0.05 \\
\hline 65 & Financial intermediation & 152 & 0.08 & 0.73 & 0.06 \\
\hline 66 & Insurance and pension funding & 26 & 0.15 & 0.80 & 0.06 \\
\hline 67 & Activities auxiliary to financial intermediation & 32 & 0.13 & 0.38 & 0.05 \\
\hline 70 & Real estate services & 65 & 0.09 & 0.03 & 0.00 \\
\hline 72 & Computer and related services & 15 & 0.07 & 0.38 & 0.01 \\
\hline 73 & Research and development & 8 & 0.00 & 0.02 & 0.00 \\
\hline 74 & Other business services & 51 & 0.12 & 0.35 & 0.02 \\
\hline Tota & & 1,532 & 0.07 & 0.13 & 0.01 \\
\hline \multicolumn{6}{|c|}{ Other industries } \\
\hline 10 & Mining of coal and lignite & 19 & 0.00 & 0.01 & 0.00 \\
\hline 11 & Extraction of crude petroleum and natural gas & 4 & 0.00 & 0.05 & 0.00 \\
\hline 14 & Other mining and quarrying & 57 & 0.11 & 0.34 & 0.02 \\
\hline 45 & Construction & 276 & 0.08 & 0.10 & 0.00 \\
\hline \multicolumn{2}{|c|}{ Total } & 356 & 0.08 & 0.08 & 0.01 \\
\hline
\end{tabular}


the leather or hotel and restaurant industries, to 0.8 in insurance and pension funding. ${ }^{15}$

We list 2-digit NACE industries in three groups: services, and high-export and low-export manufacturing. ${ }^{16}$ An industry is considered to be a "high-export" industry if it exports at least $50 \%$ of its production on average over the period $1995-2005 .^{17}$ The average share of foreign-owned assets in our three groups of industries ranges from $13 \%$ in the service sector to $38 \%$ in the high-export manufacturing industries. Similarly, the share of foreign capital in a given industry in acquisitions (as opposed to greenfields) is the lowest in the service sector. Most foreign investors in services apparently build greenfields, which may reflect the relatively low Czech share of employment in the service sector in EU comparison.

For the purpose of comparing foreign takeover effects in Section 5, we also use another alternative industry categorization. Specifically, instead of dividing manufacturing industries based on strong exporting performance, we also grouped them based on the extent to which they face international competition on the local market. Specifically, we measure industry import penetration (again, as a share of production using OECD-data averages over the period 1995-2005 as we did with export shares) and divide industries into below- and above-average import penetration groups. With reference to the industry definitions provided in Table 3, low-import industries are $15,18,20,22,23,26,28,34$, and 36 . This group therefore shares six industries with the low-export group and three with the high-export group.

Next, Table 4 provides summary statistics of all firm-level variables used in the estimation. (All relevant variables were converted to real values using industryspecific deflators.) ${ }^{18}$ Balance-sheet information is used to form four corporate performance indicators: the ratio of profit to total assets; a simple measure of total factor productivity (TFP corresponds to the residuals from the OLS industry-specific firmfixed-effect regressions of company value added on fixed assets and staff costs); ${ }^{19}$ and the company wage bill (unfortunately, employment is not available), which is also used as the share in company total assets (similar to profits over total assets).

${ }^{15}$ To check the representativeness of the ASPEKT data with respect to foreign ownership, we compare the official FDI figures (from the CNB) listed in the third column of Table 3 with estimates of the share of foreign fixed assets based on our sample (calculated by summing the capital of both foreign acquisitions and greenfields). The correlation between the two measures across 2-digit NACE industries, weighted by the share of fixed assets of each industry covered by the sample, is 0.96 .

${ }^{16}$ A small group of "other industries" is also included in the data when we analyze all industries.

${ }^{17}$ The output and export statistics were obtained from the OECD. We alternatively defined high-export manufacturing industries using only the 1995-1997 time window, which led to the reclassification of four 2-digit NACE categories from the "high-export" to the "low-export" group; this change, however, had no material effect on the estimated effects of foreign acquisition reported in the next section. The same applied when we used OECD data on Slovak industries to classify Czech industries.

${ }^{18}$ The producer price index data comes from the Czech Statistical Office.

${ }^{19}$ Our results are not materially affected when we drop the firm fixed effects from the TFP regression. Ideally, one should acknowledge that inputs in the production function are unlikely to be exogenous and apply the techniques proposed by Olley and Pakes (1996) or Levinsohn and Petrin (2003). However, this methodology requires information about investment, materials, or energy inputs, which are not available in our data. Further, the frequently applied Olley-Pakes correction rests on the assumption that factors fully adjust to shocks in each period and markets are perfectly competitive, which may not hold in a transition economy. When Javorcik (2004) introduces the Olley-Pakes procedure in a similar exercise, most of the estimated coefficients are virtually identical. 


\section{Table 4 Summary Statistics}

All financial variables are in million euros, 2000 prices. Total factor productivity (TFP) is measured as the residuals from the firm-fixed-effect regressions of value added on fixed assets and staff costs by 2-digit NACE industry. The matched sample is defined based on the p-score estimation from the first column of Table 6.

\begin{tabular}{|c|c|c|c|c|c|c|c|c|}
\hline \multirow[b]{2}{*}{ variable } & \multicolumn{4}{|c|}{ whole sample } & \multicolumn{4}{|c|}{ matched sample } \\
\hline & $\begin{array}{l}\text { observa- } \\
\text { tions }\end{array}$ & mean & median & $\begin{array}{c}\text { std. } \\
\text { deviation }\end{array}$ & $\begin{array}{l}\text { observa- } \\
\text { tions }\end{array}$ & mean & median & $\begin{array}{c}\text { std. } \\
\text { deviation }\end{array}$ \\
\hline Total assets & 26,143 & 21.29 & 3.78 & 146.79 & 10,240 & 24.04 & 4.44 & 174.73 \\
\hline Age & 26,055 & 6.61 & 6.00 & 4.37 & 10,240 & 6.97 & 7.00 & 3.86 \\
\hline Profit & 26,145 & 0.54 & 0.07 & 10.41 & 10,240 & 0.49 & 0.10 & 10.49 \\
\hline Value added & 24,077 & 4.08 & 0.98 & 23.26 & 9,915 & 4.42 & 1.12 & 25.23 \\
\hline Wage bill & 17,528 & 1.73 & 0.51 & 5.86 & 7,642 & 1.81 & 0.56 & 6.47 \\
\hline Fixed assets & 25,503 & 13.35 & 1.74 & 126.35 & 10,194 & 15.66 & 2.01 & 149.63 \\
\hline Staff costs & 25,127 & 1.95 & 0.59 & 7.28 & 10,222 & 2.19 & 0.70 & 8.50 \\
\hline $\begin{array}{l}\text { Profit to total } \\
\text { assets }\end{array}$ & 26,125 & 0.00 & 0.02 & 2.23 & 10,240 & 0.02 & 0.03 & 0.20 \\
\hline $\begin{array}{l}\text { Wage bill to total } \\
\text { assets }\end{array}$ & 17,522 & 0.24 & 0.12 & 1.79 & 7,642 & 0.18 & 0.12 & 0.25 \\
\hline TFP & 21,679 & 0.05 & 1.15 & 23.76 & 9,623 & -0.22 & 0.82 & 20.86 \\
\hline
\end{tabular}

We view these performance indicators as complementary. For instance, if productivity increases are reflected fully in rising wages, they will not be detected in our TFP indicator; instead, provided that employment is not declining, they will be captured using the wage bill measure. Next, performance indicators may be noisier in the service sector (Giovannini and Cave, 2005). More specifically, TFP is potentially an imperfect measure of productivity outside manufacturing due to the importance of intangibles in the service sector. One might therefore prefer a measure such as return on assets (ROA), which is not available in our data. However, our profits-over-totalassets measure is similar to $\mathrm{ROA}^{20}$ so this is our preferred performance measure in services. The study of the evolution of wages per unit of assets is motivated by the fact that company size can also be affected by foreign takeover. Finally, while we cannot separate employment from wage rate effects, we believe that the overall wage bill, which summarizes the two effects, is a useful summary measure of foreign takeover effects from the workers' perspective.

Table 4 provides descriptive statistics not only for the original sample, but also for the matched sub-sample of firms where the "treatment" and "control" firms used are only those that could be matched to their counterparts based on the estimated propensity score within industry and year cells. ${ }^{21}$ Imposing the common support condition leads to shedding of almost half of the data, suggesting that common support is indeed a relevant concern in our estimation. In particular, several of the service-sector industries are lost from the matching comparison, including telecommunications and computer services. ${ }^{22}$

\footnotetext{
${ }^{20}$ ROA equals net income over total assets. In contrast, our profits over total assets measure is based on the operating profit measure, which does not adjust for interest and taxes.

${ }^{21}$ The propensity score controls for profits over total assets as well as for other firm-level variables; see Table 6 for details.

${ }^{22}$ Matching also effectively excludes observations with extreme values of profits over total assets. Dropping those observations manually (i.e., those that exceed 0.15 in absolute value) does not lead to sizeable changes in the estimated coefficients.
} 
Table 5 OLS-based Performance Comparison of Ownership Types

The least-squares regressions ask whether foreign-owned firms out-perform domestic-owned ones on average within years and industries.

\begin{tabular}{lcccc}
\hline & Profit/TA & TFP & Wage Bill/TA & Wage Bill \\
\hline Foreign & -0.016 & $0.119^{\star \star \star}$ & $-0.729^{\star}$ & $0.211^{\star \star \star}$ \\
& $(0.019)$ & $(0.022)$ & $(0.373)$ & $(0.044)$ \\
Foreign-2Y-prior & -0.369 & 0.068 & $-0.168^{\star}$ & $0.278^{\star \star \star}$ \\
& $(0.275)$ & $(0.043)$ & $(0.086)$ & $(0.097)$ \\
Foreign greenfield & $0.055^{\star \star \star}$ & $0.232^{\star \star \star}$ & $0.915^{\star}$ & $0.346^{\star \star \star}$ \\
& $(0.020)$ & $(0.024)$ & $(0.477)$ & $(0.047)$ \\
In SC & $0.019^{\star \star *}$ & & & \\
& $(0.006)$ & & & \\
In FA & & & & $0.408^{\star \star \star}$ \\
& & & & $(0.005)$ \\
NACE*year dummies & yes & yes & yes & yes \\
$N$ & 30,660 & 26,449 & 21,738 & 21,505 \\
$R^{2}$ & 0.024 & 0.039 & 0.014 & 0.367 \\
\hline
\end{tabular}

Notes: SC stands for staff costs, FA is company fixed assets, "Foreign" is a dummy that equals 1 for all years after a foreign acquisition, "Foreign-2Y-prior" is a dummy that equals 1 during the two years before the entry of foreign equity into a domestic company, "Foreign greenfield" is a dummy that equals 1 for foreign-owned greenfields. Domestic-owned companies are in the base group. Robust standard errors are in parentheses.

Significance at the $1 \%, 5 \%$, and $10 \%$ levels is denoted by ${ }^{* * *},{ }^{* *}$, and ${ }^{*}$, respectively.

Before estimating the causal effects of foreign ownership, we provide one last descriptive comparison. Specifically, we ask whether foreign-owned firms outperform domestic-owned ones on average within years and industries. We answer this descriptive question by running a simple OLS regression with our panel data (including greenfields), where we condition on the interaction of year and 2-digit NACE industry dummies as well as three ownership indicators: a dummy that equals 1 during the two years before the entry of foreign equity into a domestic company; a dummy that equals 1 for all years after the foreign acquisition; and a separate dummy for foreign-owned greenfields; domestic-owned companies are the base group. The results are presented in Table 5.

Using such simple comparisons, and additionally controlling for the logarithm of firm staff costs, we find that greenfields have a statistically significantly higher level of profits over total assets (by 0.06) compared to domestic-owned companies, while the differences between domestic-owned company-year observations and those for firms (about to be) acquired by foreign investors are not statistically discernible. Similarly, using TFP as the dependent variable, and conditioning only on yearindustry dummies, we find that all foreign-owned companies display statistically significantly higher productivity, with the effect being higher (at 0.23 ) for greenfields than for acquisitions (0.12). Ownership comparisons based on wage bills normalized by total assets in the third column of Table 5 confirm the dominant position of greenfields, but result in negative coefficients for foreign takeovers. In contrast, using the wage bill as the dependent variable and controlling for the logarithm of firm fixed assets, we find that all three foreign-ownership dummy coefficients are positive and statistically significant, ranging from 0.21 for foreign acquisitions to 0.35 for green- 
fields. This set of estimates is consistent with faster growth of assets relative to wage bills after (prior to) entry of foreign equity. For comparative purposes, we prefer the last specification as it controls for size in a flexible manner consistent with standard estimates in the literature. In sum, among Czech companies, foreign ownership appears to be associated with higher productivity, profits, or wage bills. In particular, greenfields attain the highest level for each of our performance indicators, as expected, which is reassuring in terms of the quality of the indicator definitions.

\section{Main Results}

\subsection{Propensity Score Estimation}

Our first task is to estimate the propensity score - the probability that an individual firm with certain characteristics is acquired by a foreign entity in a given year. Such analysis is interesting in its own right, and it also provides the key continuous conditioning variable for the matching exercise. A set of logit specifications for the probability of foreign takeover is reported in Table 6. The propensity score is predicted based on company age and either fixed assets or staff costs (depending on the outcome performance measure: profit or wage bill over assets, wage bill, and TFP); each specification then additionally controls for the level of the outcome variable from one and two years prior to the current year, which is meant to control for both the pretakeover level of and the recent trend in performance. ${ }^{23}$

Older firms are more likely to be acquired, as are larger firms and those with higher staff costs. A positive (negative) trend in profitability (productivity) appears to predict the chances of a foreign takeover. For example, taking the statistically insig-nificant coefficient on the profit level from time $t-1$ as corresponding to a nearzero coefficient, the estimates in the first column correspond to a positive 0.005 coefficient on the trend in profits over assets (i.e., the change between the lagged profitability indicator from $t-1$ and $t-2$ ). Put differently, higher lagged TFP level is associated with a higher probability of foreign equity entering a given firm. Wage bills do not predict foreign equity entry, but higher levels of wage bills per total assets lower the chances of a takeover. ${ }^{24}$ These propensity scores, which are consistent with foreign investors "cherry picking" domestic firms, are used in the difference-in-differences with matching estimation in the next section. ${ }^{25}$

\footnotetext{
${ }^{23}$ We choose the conditioning set for each outcome measure separately to allow for maximum control for "cherry picking" on the relevant measure while retaining a parsimonious specification. Similarly, we exclude staff costs and fixed assets from the TFP-relevant propensity score, as this outcome measure (its lagged values) already controls for these two variables.

${ }^{24}$ The estimated propensity score coefficients are not materially affected when we add 2-digit industry and year dummies, i.e., the variables on which we match "exactly".

${ }^{25}$ To assess how well the propensity score performed in balancing observables across the matched treatment and controls, we performed two-sample $t$-tests suggested by Rosenbaum and Rubin (1985) and evaluated the pseudo $R^{2}$ statistics before and after matching. There were no systematic differences in the distribution of covariates after matching and the pseudo- $R^{2}$ was close to zero $(0.01$, down from 0.06 before matching). Similar conclusions come from $F$-tests on the joint significance of all regressors. However, one may be concerned that since the share of domestic companies in our sample is shrinking over time (from $88 \%$ to $65 \%$ ), the quality of the match could be deteriorating over time as well. For this reason, we performed a series of $t$-tests using subsamples based on 4-year moving windows of the data. The evolution of the pseudo- $R^{2}$ values measured after matching does suggest some deterioration in match quality over time, with a threefold rise over the sample frame, but the values generally stay under 0.1 .
} 
Table 6 P-score Estimation

The table presents the marginal effects from Logit estimation asking whether a domestic company becomes foreign-owned.

\begin{tabular}{|c|c|c|c|c|}
\hline Age & $\begin{array}{l}0.015^{\star * *} \\
(0.002)\end{array}$ & $\begin{array}{l}0.017^{\star * \star} \\
(0.002)\end{array}$ & $\begin{array}{l}0.016^{* * *} \\
(0.003)\end{array}$ & 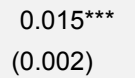 \\
\hline $\mathrm{Age}^{2}$ & $\begin{array}{l}-0.0003^{\star \star *} \\
(0.0001)\end{array}$ & $\begin{array}{l}-0.0003^{* * *} \\
(0.0001)\end{array}$ & $\begin{array}{l}-0.0002^{\star * *} \\
(0.0001)\end{array}$ & $\begin{array}{l}-0.0002^{\star \star *} \\
(0.0001)\end{array}$ \\
\hline In $S C_{t-1}$ & $\begin{array}{l}0.017^{\star \star \star} \\
(0.002)\end{array}$ & & & \\
\hline $\ln F A_{t-1}$ & & & & $\begin{array}{l}0.014^{\star \star *} \\
(0.003)\end{array}$ \\
\hline PROFIT/TA $A_{t-1}$ & $\begin{array}{c}0.004 \\
(0.004)\end{array}$ & & & \\
\hline PROFIT/TA $A_{t-2}$ & $\begin{array}{l}-0.005^{\star \star} \\
(0.002)\end{array}$ & & & \\
\hline In $T F P_{t-1}$ & & $\begin{array}{l}0.005 \\
(0.004)\end{array}$ & & \\
\hline In $T F P_{t-2}$ & & $\begin{array}{l}0.011^{\star * *} \\
(0.004)\end{array}$ & & \\
\hline WAGE BILL/TA $A_{t-1}$ & & & $\begin{array}{l}-0.063^{* *} \\
(0.032)\end{array}$ & \\
\hline$W A G E B I L L / T A_{t-2}$ & & & $\begin{array}{c}0.0003 \\
(0.0017)\end{array}$ & \\
\hline In WAGE BILL $L_{t-1}$ & & & & $\begin{array}{l}-0.009 \\
(0.010)\end{array}$ \\
\hline In WAGE BILL $L_{t-2}$ & & & & $\begin{array}{c}0.015 \\
(0.010) \\
\end{array}$ \\
\hline$N$ & 17,274 & 16,194 & 12,217 & 12,149 \\
\hline$x^{2}$ & 188.132 & 141.553 & 95.07 & 125.229 \\
\hline pseudo $R^{2}$ & 0.065 & 0.045 & 0.045 & 0.076 \\
\hline
\end{tabular}

Notes: Age stands for years since company incorporation, FA stands for company fixed assets, SC is staff costs, TA is total assets, PROFIT stands for profit/loss, and TFP denotes company total factor productivity. All financial variables are in thousands of CZK. Robust standard errors are in parentheses; they have been corrected for clustering at company level.

Significance at the $1 \%, 5 \%$, and $10 \%$ levels is denoted by ${ }^{* *},{ }^{* *}$, and ${ }^{*}$, respectively.

We also estimated propensity scores separately for the industry groups displayed in Table 3 (these results are available upon request). Although noisy, these estimates suggest differences in takeover strategies. The pre-acquisition trend in profits over assets comes mainly from the service sector, while the estimates for the low-export sector are less consistent with "cherry picking," perhaps suggesting that company performance may be less important for the acquisition decision in this sector. $^{26}$

${ }^{26}$ In an earlier version of the paper, we also found that while the existence of greenfield FDI does not predict future takeover probability at the industry level, a higher share of takeovers in industry fixed assets does predict future foreign equity entry. 
Table 7 Matching Results-Profit per Total Assets

The table presents a comparison of the change in performance of companies taken over by foreign investors between one year before acquisition and one to three years after acquisition with the corresponding change in performance of matched domestic companies. See Section 3 for industry grouping. The performance measure is profit over total assets (PROFIT/TA).

\begin{tabular}{lcccccc}
\hline & All & Low-export & \multicolumn{2}{c}{ Manufacturing } & High-import & Services \\
& industries & & & High-export & Low-import & \\
\hline$t+1$ & 0.032 & $0.058^{*}$ & 0.018 & $0.078^{*}$ & 0.006 & -0.008 \\
& $(0.027)$ & $(0.034)$ & $(0.022)$ & $(0.043)$ & $(0.026)$ & $(0.023)$ \\
$N$ & 12,993 & 5,580 & 2,899 & 5,249 & 3,230 & 3,463 \\
$N$ treated matched & 207 & 100 & 47 & 89 & 58 & 41 \\
$N$ controls matched & 12,760 & 5,469 & 2,844 & 5,147 & 3,166 & 3,416 \\
$t+2$ & $0.210^{* * *}$ & 0.138 & -0.003 & $0.151^{* * *}$ & -0.006 & 0.023 \\
& $(0.085)$ & $(0.090)$ & $(0.108)$ & $(0.038)$ & $(0.025)$ & $(0.041)$ \\
$N$ & 10,275 & 4,477 & 2,332 & 4,206 & 2,603 & 2,647 \\
$N$ treated matched & 172 & 84 & 40 & 74 & 54 & 33 \\
$N$ controls matched & 10,075 & 4,383 & 2,282 & 4,121 & 2,544 & 2,609 \\
$t+3$ & -0.073 & -0.017 & -0.028 & 0.019 & -0.224 & 0.020 \\
& $(0.067)$ & $(0.191)$ & $(0.036)$ & $(0.024)$ & $(0.201)$ & $(0.054)$ \\
$N$ & 7,935 & 3,500 & 1,833 & 3,284 & 2,049 & 1,984 \\
$N$ treated matched & 143 & 70 & 38 & 60 & 46 & 25 \\
$N$ controls matched & 7,766 & 3,421 & 1,788 & 3,213 & 1,996 & 1,954 \\
\hline
\end{tabular}

Notes: Bootstrapped standard errors are in parentheses; they have been corrected for clustering at company level.

Significance at the $1 \%, 5 \%$, and $10 \%$ levels is denoted by ${ }^{* *},{ }^{* *}$, and ${ }^{*}$, respectively.

\subsection{Foreign-Ownership Effects}

In this section, we report the results of the matched difference-in-differences analysis of the performance change gap between domestic and foreign companies one to three years after acquisition. Tables 7 to 10 show the results for the four performance indicators we study. There is no clear pattern of takeover effects in wage bills per total assets and the estimated effects are small. For the other three performance indicators, however, we find that foreign ownership leads to substantial improvements in corporate performance in low-export and low-import manufacturing industries, with the strongest impact two to three years after the foreign takeover. ${ }^{27}$ The estimated effects are remarkably similar in the low-import and low-export groups. In contrast, the results imply no significant effects (with the exception of one coefficient out of the 36 estimated) for manufacturing industries exposed to international competition and in the service sector. The findings thus suggest that high industry openness defined using both export and import shares curbs the effects of foreign acquisitions on company performance. The absence of takeover effects in the service sector could correspond to market regulation or performance measurement issues in services.

The magnitude of the estimated effects in the low-import (low-export) industries is economically significant, too. For example, the two-year change in profits

${ }^{27}$ Girma et al. (2007) uncover a similar time pattern in their study of foreign ownership effects. 


\section{Table 8 Matching Results-Total Factor Productivity}

The table presents a comparison of the change in performance of companies taken over by foreign investors between one year before acquisition and one to three years after acquisition with the corresponding change in performance of matched domestic companies. See Section 3 for industry grouping. The performance measure is the logarithm of total factor productivity (In TFP); see Table 4 for the definition of TFP.

\begin{tabular}{|c|c|c|c|c|c|c|}
\hline & $\begin{array}{c}\text { All } \\
\text { industries }\end{array}$ & Low-export & $\begin{array}{r}\text { Manufac } \\
\text { High-export }\end{array}$ & $\begin{array}{l}\text { cturing } \\
\text { Low-import }\end{array}$ & $\begin{array}{l}\text { High- } \\
\text { import }\end{array}$ & Services \\
\hline \multirow[t]{2}{*}{$t+1$} & 0.006 & -0.031 & 0.058 & 0.002 & -0.074 & 0.016 \\
\hline & $(0.065)$ & $(0.056)$ & $(0.088)$ & $(0.056)$ & $(0.121)$ & $(0.163)$ \\
\hline$N$ & 12,196 & 5,396 & 2,788 & 5,081 & 3,116 & 3,032 \\
\hline$N$ treated matched & 205 & 104 & 42 & 93 & 54 & 33 \\
\hline$N$ controls matched & 11,991 & 5,292 & 2,746 & 4,981 & 3,057 & 2,999 \\
\hline \multirow[t]{2}{*}{$t+2$} & 0.063 & 0.011 & 0.007 & 0.021 & -0.007 & -0.119 \\
\hline & $(0.057)$ & $(0.053)$ & $(0.109)$ & $(0.098)$ & $(0.126)$ & $(0.223)$ \\
\hline$N$ & 9,623 & 4,309 & 2,230 & 4,052 & 2,502 & 2,323 \\
\hline$N$ treated matched & 176 & 85 & 39 & 79 & 48 & 28 \\
\hline$N$ controls matched & 9,447 & 4,224 & 2,191 & 3,969 & 2,446 & 2,295 \\
\hline \multirow[t]{2}{*}{$t+3$} & $0.157^{\star \star \star}$ & $0.151^{* *}$ & 0.075 & $0.195^{\star *}$ & 0.016 & 0.038 \\
\hline & $(0.051)$ & $(0.076)$ & $(0.148)$ & $(0.094)$ & $(0.081)$ & $(0.341)$ \\
\hline$N$ & 7,408 & 3,354 & 1,748 & 3,146 & 1,967 & 1,736 \\
\hline$N$ treated matched & 147 & 73 & 34 & 66 & 41 & 22 \\
\hline$N$ controls matched & 7,261 & 3,281 & 1,714 & 3,077 & 1,918 & 1,714 \\
\hline
\end{tabular}

Notes: See Table 7.

\section{Table 9 Matching Results-Wage Bill per Total Assets}

The table presents a comparison of the change in performance of companies taken over by foreign investors between one year before acquisition and one to three years after acquisition with the corresponding change in performance of matched domestic companies. See Section 3 for industry grouping. The performance measure is wages over total assets (WAGE BILL/TA).

\begin{tabular}{lcccccc}
\hline & $\begin{array}{c}\text { All } \\
\text { industries }\end{array}$ & Low-export & $\begin{array}{c}\text { Manufacturing } \\
\text { High-export }\end{array}$ & $\begin{array}{c}\text { High- } \\
\text { import }\end{array}$ & Services \\
\hline$t+1$ & $-0.018^{* *}$ & -0.008 & -0.013 & -0.006 & -0.007 & -0.041 \\
& $(0.008)$ & $(0.008)$ & $(0.036)$ & $(0.047)$ & $(0.008)$ & $(0.042)$ \\
$N$ & 9,209 & 4,278 & 2,164 & 3,954 & 2,494 & 2,139 \\
$N$ treated matched & 151 & 79 & 37 & 70 & 45 & 27 \\
$N$ controls matched & 9,058 & 4,199 & 2,127 & 3,880 & 2,446 & 2,112 \\
$t+2$ & $-0.013^{*}$ & -0.011 & -0.001 & -0.048 & $-0.019 *$ & -0.020 \\
& $(0.008)$ & $(0.013)$ & $(0.032)$ & $(0.106)$ & $(0.009)$ & $(0.046)$ \\
$N$ & 7,309 & 3,436 & 1,748 & 3,174 & 2,018 & 1,638 \\
$N$ treated matched & 131 & 66 & 34 & 57 & 42 & 22 \\
$N$ controls matched & 7,178 & 3,370 & 1,714 & 3,110 & 1,974 & 1,616 \\
$t+3$ & 0.002 & -0.006 & -0.010 & 0.002 & 0.001 & -0.027 \\
& $(0.027)$ & $(0.023)$ & $(0.038)$ & $(0.021)$ & $(0.020)$ & $(0.034)$ \\
$N$ & 5,658 & 2,694 & 1,378 & 2,486 & 1,594 & 1,223 \\
$N$ treated matched & 113 & 54 & 32 & 48 & 39 & 19 \\
$N$ controls matched & 5,545 & 2,640 & 1,346 & 2,433 & 1,553 & 1,204 \\
\hline
\end{tabular}

Notes: See Table 7. 
Table 10 Matching Results-Wage Bill

The table presents a comparison of the change in performance of companies taken over by foreign investors between one year before acquisition and one to three years after acquisition with the corresponding change in performance of matched domestic companies. See Section 3 for industry grouping. The performance measure variable is the logarithm of the company wage bill (In WAGE BILL).

\begin{tabular}{lcccccc}
\hline & All & \multicolumn{3}{c}{ Manufacturing } & High-import & \multirow{2}{*}{ Services } \\
& industries & Low-export & High-export & Low-import & & \\
\hline$t+1$ & 0.060 & $0.148^{*}$ & -0.146 & 0.065 & -0.032 & 0.216 \\
& $(0.051)$ & $(0.085)$ & $(0.113)$ & $(0.048)$ & $(0.107)$ & $(0.298)$ \\
$N$ & 9,182 & 4,276 & 2,165 & 3,948 & 2,493 & 2,116 \\
$N$ treated matched & 135 & 68 & 33 & 59 & 43 & 24 \\
$N$ controls matched & 9,021 & 4,193 & 2,126 & 3,874 & 2,445 & 2,086 \\
$t+2$ & 0.052 & $0.295^{* * *}$ & -0.200 & 0.179 & -0.086 & -0.256 \\
& $(0.059)$ & $(0.094)$ & $(0.269)$ & $(0.111)$ & $(0.157)$ & $(0.248)$ \\
$N$ & 7,295 & 3,438 & 1,749 & 3,170 & 2,017 & 1,626 \\
$N$ treated matched & 111 & 61 & 29 & 53 & 37 & 18 \\
$N$ controls matched & 7,155 & 3,366 & 1,713 & 3,106 & 1,973 & 1,601 \\
$t+3$ & 0.036 & 0.288 & -0.378 & $0.344^{* *}$ & -0.121 & -0.816 \\
& $(0.152)$ & $(0.198)$ & $(0.272)$ & $(0.168)$ & $(0.142)$ & $(0.706)$ \\
$N$ & 5,655 & 2,698 & 1,379 & 2,484 & 1,593 & 1,219 \\
$N$ treated matched & 90 & 51 & 28 & 40 & 34 & 12 \\
$N$ controls matched & 5,534 & 2,638 & 1,345 & 2,431 & 1,552 & 1,198 \\
\hline
\end{tabular}

Notes: See Table 7.

over assets driven by a foreign acquisition corresponds to about one-tenth of the fullsample standard deviation of all the observed two-year changes in this variable. Focusing on the TFP performance measure and using the estimate from three years after the foreign acquisition, the effect corresponds to about one-quarter of the fullsample standard deviation in these three-year changes. Finally, the impact of a foreign acquisition on the change in the (log) wage bill, and therefore on the workers subject to foreign takeover, is certainly economically significant at 30 percentage points of the wage bill growth rate above domestically owned firms two to three years after the acquisition. The timing of the onset of these effects in low-export/low-import manufacturing industries, with profits rising early on, wage bills throughout, and TFP only in year $t+3$, is consistent with the presence of some short-term ("low-hanging") profit opportunities implemented after takeover, such as the sale of non-core assets. ${ }^{28}$ Our results for total factor productivity and wage bills are in line with those from Arnold and Javorcik (2009), although their estimated effects of foreign acquisitions in Indonesia are substantially larger in magnitude. ${ }^{29}$

\footnotetext{
${ }^{28}$ The early improvement in profits predating improvements in productivity could also be due to higher market power (markups). However, one would expect such market power to remain visible in profitability improvements in later periods as well.
} 


\section{Conclusion}

There is a large literature studying the effects of ownership changes during early-transition privatization, but much less work on the effects of recent FDI, which is, arguably, the more important "engine of growth" in post-communist countries. Furthermore, most of the FDI-related research focuses on its indirect effect, such that we know comparatively little about the direct effect of foreign takeovers on domestic companies and the choices of mode of foreign-market access (greenfield vs. brownfield) that foreign investors make.

Based on data covering the experience of Czech companies around the time of the Czech Republic's entry into the EU and using the matched difference-indifferences approach, we find that foreign takeovers significantly boost several corporate performance indicators in manufacturing industries facing less international competition (on local or international markets), but have little effect in other industries. Workers of these firms benefit from the acquisitions as well in terms of their total wage bills. (We are unable to decompose the wage bill effects into wage and employment effects.) These findings are consistent with the argument that domestic-owned firms in manufacturing industries that face direct international competition do not need to be "disciplined" by foreign owners. ${ }^{30}$ Our study complements the results of Alfaro (2003), who, in a cross-country study of FDI effects, finds that manufacturing FDI generates a positive growth effect, while the impact is ambiguous in the service sector. The absence of a statistically or economically significant effect of takeovers on service-sector firms may be driven by market regulation or structure and motivates future work on service-sector FDI.

\footnotetext{
${ }^{29}$ We performed a number of robustness checks, which signaled little sensitivity of these conclusions to sample choices or to details of the estimation technique. Among other checks, we tried dropping the last year of the sample (2005), where there is somewhat less data, and we also experimented with using only industries where the sample coverage of the firm population was above the 30th percentile of the industry distribution of coverage. Instead of following the performance indicators for each year after the acquisition separately, we additionally re-estimated the matching exercises while focusing on 2-year and 3-year moving average windows of performance, and we also assessed the sensitivity to defining exporting industries using 1995-1997 data instead of the whole sample period and using Slovak industry trade data instead of Czech. Finally, we estimated the effects using panel-data techniques, controlling for company fixed effects and company time trends, but using only those domestic firms which could be matched to takeover firms. The results were consistent with those reported here and are available upon request.

${ }^{30}$ In a related analysis, Konings et al. (2003) suggest that exposure to international trade and competition is one of the key driving forces of the restructuring of Ukrainian firms during 1998-2000.
} 


\section{REFERENCES}

Aitken BJ, Harrison AE (1999): Do Domestic Firms Benefit from Direct Foreign Investment? Evidence from Venezuela. American Economic Review, 89(3):605-618.

Alfaro L (2003): FDI and Economic Growth Does the Sector Matter?

http://www.people.hbs.edu/lalfaro/fdisectorial.pdf, unpublished manuscript.

Alfaro L, Areendam C, Kalemli-Ozcan S, Sayek S (2004): FDI and Economic Growth: The Role of the Financial Markets. Journal of International Economics, 64(1):89-112.

Arnold J, Javorcik BS (2009): Gifted Kids or Pushy Parents? Foreign Direct Investment and Plant Productivity in Indonesia. Journal of International Economics, 79(1):42-53.

Barba Navaretti G, Venables AJ (2004): Multinational Firms in the World Economy. Princeton University Press, Princeton, NJ.

Barsky R, Bound J, Charles K, Lupton J (2002): Accounting for the Black-White Wealth Gap: A Nonparametric Approach. Journal of the American Statistical Association, 97:663-673.

Bellak C (2004): How Domestic and Foreign Firms Differ and Why Does it Matter? Journal of Economic Surveys, 18(4):483-514.

Benfratello L, Sembenelli A (2006): Foreign Ownership and Productivity: Is the Direction of Causality so Obvious? International Journal of Industrial Organization, 24:733-751.

Blundell R, Costa Dias M (2000): Evaluation Methods for Non-Experimental Data. Fiscal Studies, 21(4):427-468.

Blundell R, Costa Dias M (2009): Alternative Approaches to Evaluation in Empirical Microeconomics. Journal of Human Resources, 44(3):565-640.

Brown JD, Earle JS, Telegdy A (2006): The Productivity Effects of Privatization: Longitudinal Estimates from Hungary, Romania, Russia, and Ukraine. Journal of Political Economy, 114(1):61-99.

Brown JD, Earle JS, Telegdy A (2010): Employment and Wage Effects of Privatization: Evidence from Hungary, Romania, Russia, and Ukraine. Economic Journal, 120(545):683-708.

Campos NF, Kinoshita Y (2003): Why Does FDI Go Where it Goes? New Evidence from the Transition Economies. IMF Working Paper, No. 228.

Conyon MJ, Girma S, Thompson S, Wright PW (2002): The Productivity and Wage Effects of Foreign Acquisition in the United Kingdom. Journal of Industrial Economics, 50(1):85-102.

Damijan JP, Knell M, Majcen B, Rojec M (2003): The Role of FDI, R\&D Accumulation and Trade in Transferring Technology to Transition Countries: Evidence from Firm Panel Data for Eight Transition Countries. Economic Systems, 27(2):189-204.

Djankov S, Hoekman B (2000): Foreign Investment and Productivity Growth in Czech Enterprises. The World Bank Economic Review, 14(1):49-64.

Djankov S, Murrell P (2002): Enterprise Restructuring in Transition: A Quantitative Survey. Journal of Economic Literature, 40:739-792.

Estrin S, Hanousek J, Kočenda E, Švejnar J (2009): Effects of Privatization and Ownership in Transition Economies. Journal of Economic Literature, 47(3):1-31.

Evenett S, Voicu A (2003): Picking Winners or Creating Them? Revisiting the Benefits of FDI in the Czech Republic. Oxford University Working Paper.

Giovannini E, Cave W (2005): The Statistical Measurement of Services: Recent Achievements and Remaining Challenges. OECD Statistics Working Papers, no. 2005/2 (OECD Publishing).

Girma S, Holger G, Strobl E (2004): Exports, International Investment, and Plant Performance: Evidence from a Non-parametric Test. Economics Letters, 83(3):317-324.

Girma S, Kneller R, Pisu M (2007): Do Exporters have Anything to Learn from Foreign Multinationals? European Economic Review, 51:981-998.

Gorodnichenko Y, Švejnar J, Terrell K (2007): When Does FDI Have Positive Spillovers? Evidence from 17 Emerging Market Economies. IZA Discussion Paper, no. 3079. 
Hanousek J, Kočenda E, Švejnar J (2007): Origin and Concentration: Corporate Ownership, Control and Performance. Economics of Transition, 15(1):1-31.

Hanousek J, Kočenda E, Švejnar J (2009): Divestitures, Privatization and Corporate Performance in Emerging Markets. Economics of Transition, 17(1):43-73.

Helpman E, Melitz MJ, Yeaple SR (2004): Export versus FDI with Heterogeneous Firms. American Economic Review, 94(1):300-316.

International Study Group on Exports and Productivity (ISGEP) (2008): Understanding CrossCountry Differences in Exporter Premia: Comparable Evidence for 14 Countries. Review of World Economics, 144(4):596-635.

Jarolím M (2000): Foreign Direct Investment and Productivity of Firms. Finance a úvěr-Czech Journal of Economics and Finance, 50(9):478-487.

Javorcik BS (2004): Does Foreign Direct Investment Increase the Productivity of Domestic Firms? In: Search of Spillovers through Backward Linkages. American Economic Review, 94(3):605-627.

Konings J, Kupets O, Lehmann H (2003): Gross Job Flows in Ukraine: Size, Ownership and Trade Effects. Economics of Transition, 11(2):321-356.

Kosová R (2010): Do Foreign Firms Crowd Out Domestic Firms? Evidence from the Czech Republic. Review of Economics and Statistics, 92(4):861-881.

Leuven E, Sianesi B (2003): Stata module to perform full Mahalanobis and propensity score matching, common support graphing, and covariate imbalance testing. Statistical Software Components S432001, Boston College Department of Economics.

Levinsohn J, Petrin A (2003): Estimating Production Functions Using Inputs to Control for Unobservables. Review of Economic Studies, 70(2):317-342.

Neuhaus M (2006): The Impact of FDI on Economic Growth: An Analysis for the Transition Countries of Central and Eastern Europe. Contributions to Economics, 12.

Nocke V, Yeaple S (2007): Cross-Border Mergers and Acquisitions versus Greenfield Foreign Direct Investment: the Role of Firm Heterogeneity. Journal of International Economics, 72:336-365.

Olley GS, Pakes A (1996): The Dynamics of Productivity in the Telecommunications Equipment Industry. Econometrica, 64(6):1263-1297.

Qiu LD, Wang S (2011): FDI Policy, Greenfield Investment and Cross-border Mergers. Review of International Economics, 19(5):836-851.

Rosenbaum P, Rubin D (1985): Constructing a Control Group Using Multivariate Matched Sampling Methods that Incorporate the Propensity Score. The American Statistician, 39(1):33-38.

Sabirianova K, Švejnar J, Terrell K (2005): Foreign Investment, Corporate Ownership, and Development: Are Firms in Emerging Markets Catching Up to the World Standard? WDI Working Paper, 734.

Stančík J (2007): Horizontal and Vertical FDI Spillovers: Recent Evidence from the Czech Republic. CERGE-EI Working Paper, no. 340. 